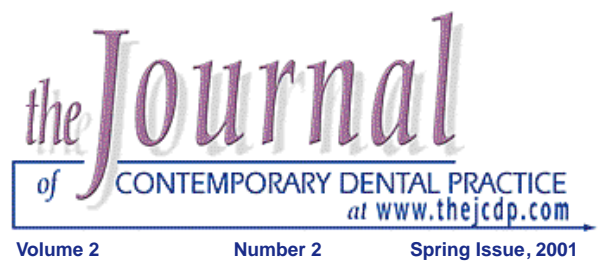

\title{
SEM Study on the Effect of Two Different Demineralization Methods with Saturated Tetracycline Hydrochloride on Diseased Root Surfaces
}

\section{Nadir Babay, DDS, MS, DESM}

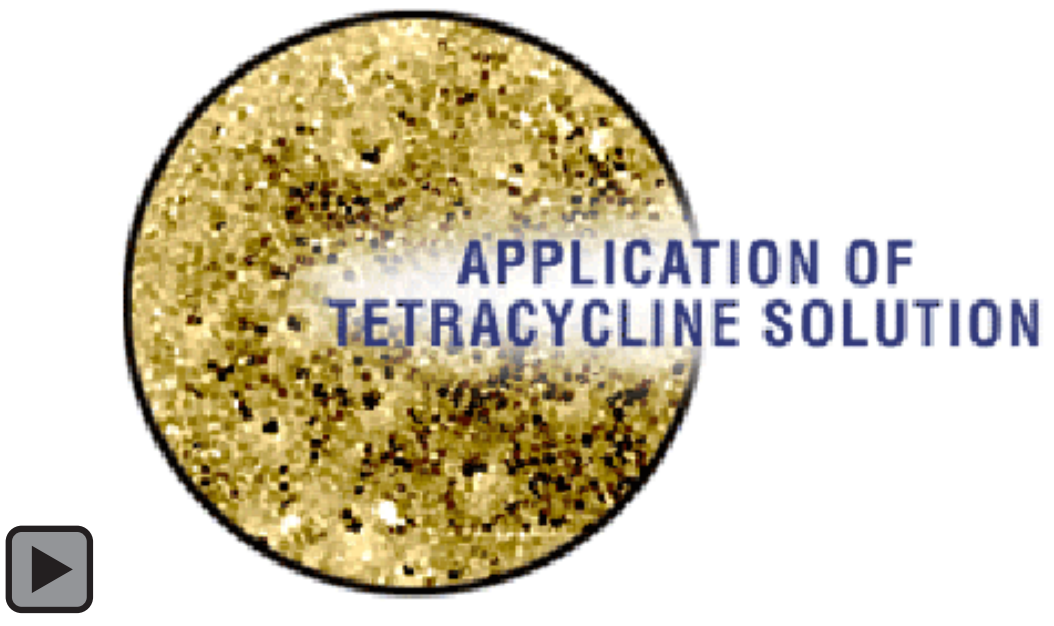

\section{Abstract}

The scanning electron microscope was used to evaluate the dentin surface of diseased teeth subjected to two methods of conditioning with tetracycline hydrochloride (TTC) for 1 and 4 minutes respectively. Five groups of twelve specimens each received root planing (control); were immersed in TTC for 1 and 4 minutes; and burnished in TTC for 1 and 4 minutes. Control specimens exhibited an amorphous irregular surface smear layer. TTC, irrespective of the method used, was effective in removing the smear I a y elmmersion in TTC for 1 minute revealed obstructed dentinal tubules, while burnishing for 1 minute revealed the presence of collagen fibrils. The 4-minute application of TTC, irrespective of the conditioning method used, showed wide exposed dentinal tubules. No significant difference between Groups III, $\mathrm{I} \bigvee$ and $\mathrm{V}$ was noted $(\mathrm{p}>0.05)$

Keywords: Tetracycline hydrochloride, TTC, smear layer, collagen fibrils, dentinal tubules 


\section{Introduction}

Several studies have clearly demonstrated bacteria and their endotoxins heavily contaminate the root surfaces of periodontally affected teeth, and

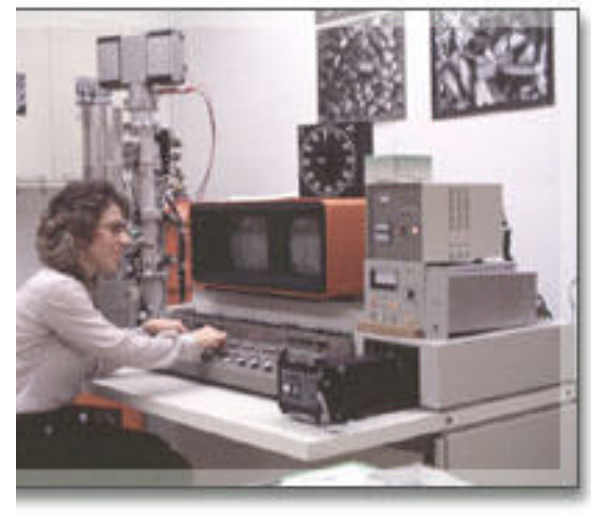
this bacterial contamination prevents the reattachment of gingival and periodontal cells. ${ }^{1,4}$

Removal of diseased exposed cementum by scaling and root planing has been advocated as part of periodontal therapy. ${ }^{5,6}$ Studies have indicated that such root debridement may not completely remove contaminated cementum particularly in more apical areas, ${ }^{7,8}$ therefore, it has been proposed to chemically condition the root surface in order to improve biocompatibility. Citric acid and tetracycline hydrochloride (TTC) are the most widely used substances for this purpose. .,10 $^{9}$

In vitro studies on the effect of TTC on dentinal surfaces have revealed properties, which may be beneficial in periodontal reconstructive therapy. Surface demineralization with TTC enhances binding of matrix proteins to the root surface and stimulates fibroblasts attachment and growth. ${ }^{11,12}$ Although these findings have led to widespread use of tetracycline treatment of root surfaces in periodontal therapy, there are conflicting reports in the literature concerning the efficacy of the demineralization methods and application time. ${ }^{13,14}$ Moreover, optimal concentration and the application interval of TTC to achieve root surface characteristics which may support periodontal reconstructive therapy have yet to be established. ${ }^{11}$

The purpose of the present study was to evaluate the characteristics of diseased root surfaces treat ed with TTC following mechanical instrumentation. The effects of methods of demineralization and application time were also determined.

\section{Materials and Methods}

\section{Dentin Block Preparation}

Twenty human teeth extracted due to severe peri odontitis were used in the present study.

Following extraction, the border between healthy and diseased root surfaces was marked with a small dental bur. Following this, each diseased root surface was thoroughly planed with periodon tal curettes. Root dentin exposure was achieved by hand and rotary instrumentation as described by Trombelli et al. ${ }^{15}$ Each root was then sectioned longitudinally as three equal parts. Using a \#2 round bur, a horizontal shallow groove was made in a apical-coronal direction on the pulpal surface of every root surface for identification purpose. The dentin specimens were about $3 \times 5 \times 2 \mathrm{~mm}$ in size. This yielded a total of sixty dentin speci mens; forty-eight experimental and twelve controls. All specimens were randomly divided into five treatment groups. The control specimens were obtained from the non-demineralized treated

\section{Group I Control}
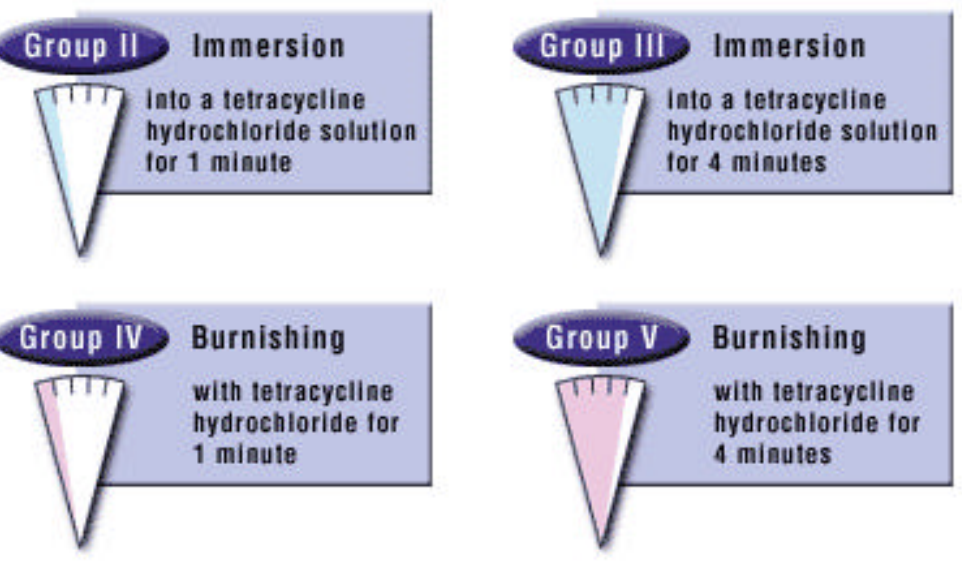

part of the root. The treatment groups were as follows:

\section{Tetracycline Solution}

A freshly made tetracycline solution was used. The TTC solution ${ }^{1}$ was prepared by slowly adding pure TTC into distilled water until a saturated solution of $0.2 \% \mathrm{~g} / \mathrm{ml}$ was obtained with constant stirring at $37^{\circ} \mathrm{C}$ for 15 minutes. This gave the solution a $\mathrm{pH}$ of 1.8 when checked with a $\mathrm{pH}$ meter. 
Table 1. Cross tabulation of the material used in the relation to the descriptive scale

\begin{tabular}{|c|c|c|c|c|c|c|}
\hline Material & \multicolumn{1}{c}{ 0 } & \multicolumn{1}{c}{ 1 } & \multicolumn{2}{c|}{3} & Total \\
\hline Group I & $11(91.7 \%)$ & $1(8.3 \%)$ & 0 & 0 & 0 & 12 \\
\hline Group II & 0 & $2(16.7 \%)$ & $4(33.3 \%)$ & $6(50.0 \%)$ & 0 & 12 \\
\hline Group III & 0 & 0 & 0 & $7(58.3 \%)$ & $5(41.7 \%)$ & 12 \\
\hline Group IV & 0 & 0 & 0 & $7(58.3 \%)$ & $5(41.7 \%)$ & 12 \\
\hline Group V & 0 & 0 & 0 & $2(16.7 \%)$ & $10(83.3 \%)$ & 12 \\
\hline $\begin{array}{c}\text { Total Count } \\
\% \text { within } \\
\text { material }\end{array}$ & 11 & 3 & 4 & 22 & 20 & 60 \\
\hline
\end{tabular}

The application time of TTC was 1 and 4 minutes. In the burnishing groups the cotton was changed every 30 seconds, and then the areas were rinsed with distilled water.

\section{SEM Study Preparations}

Each air-dried sample was sputter coated with approximately 20 to $30 \mathrm{~nm}$ of gold palladium and then examined with a scanning electron micro scope. $^{2}$

Scanning photomicrographs were obtained at $1000 \mathrm{X}$ and $2000 \mathrm{X}$ magnification. All sixty speci mens were examined and photographed at these different magnifications.

Each dentin surface was scanned in its entirety to obtain an overview of the general surface topog raphy. Photographs were taken of representative areas that were characteristic of the general sur face topography on each specimen. The dentin surfaces were examined for morphological characteristics at different magnifications. The treated surfaces were assessed for the presence of smear layer by a visual method. Assessments were made on photographs using the scale of zero to four described by Madison et al. ${ }^{16}$

0 : no removal of the smear layer

1: greater than no effect but less than one half removal

2: approximately one half removal of the smear layer

3: greater than half but less than complete removal
4: complete removal of the smear layer

Data cross tabulation of the material in relation to descriptive scale is presented in Table 1.

A Kruskal-Wallis ${ }^{17}$ was performed on these evaluations. Tukey's non parametric multiple range test was used to determine which groups were significantly different. The test was used to com pare the five groups for the presence, partial, or complete removal of smear layer.

\section{Results}

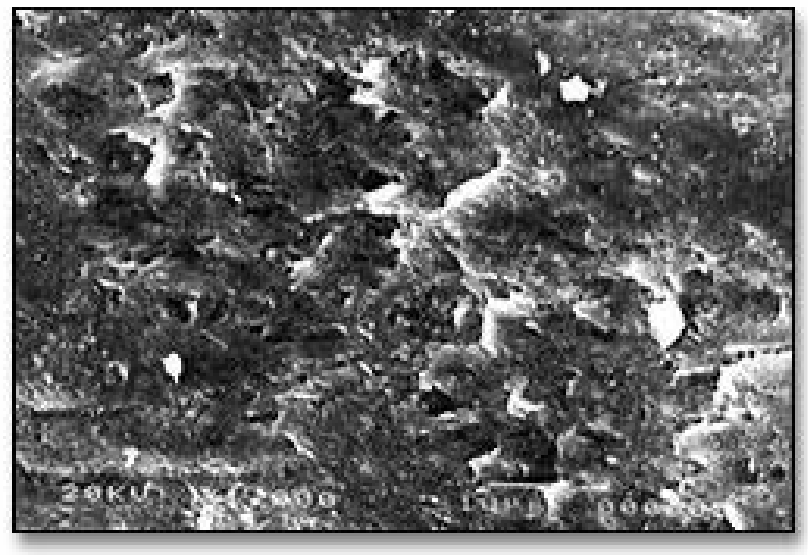

Figure 1.

Root planed treated surface (control). An amorphous irregular coating (smear layer) obscures the underlying dentinal tubules (original magnification $X 1000$ ).

In the control group, an amorphous, irregular coating previously defined as a smear layer cov 
ered the whole surface and completely obscured the underlying dentinal tubules. (Figure 1)

The roots for specimens in Group II were immersed in TTC for 1 minute. These presented a small amount of grinding debris partially occlud ing the dentinal tubules. (Figure 2)

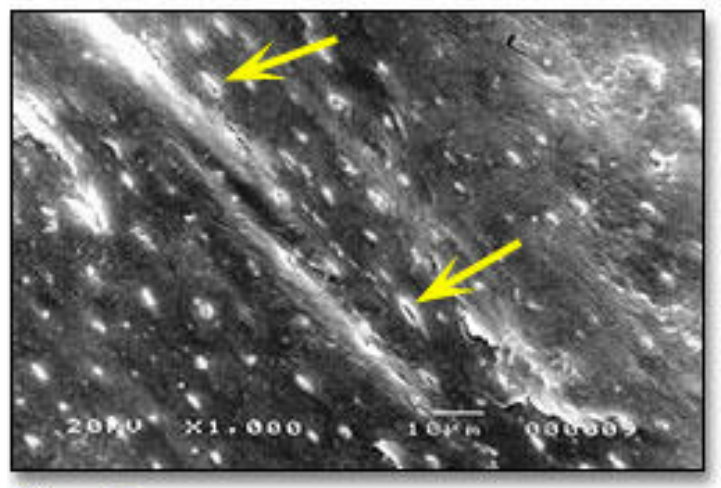

Figure 2.

Scanning electron micrograph of dentinal surface immersed in tetracycline hydrochloride for 1 minute. Dentinal tubules orifices are partially occluded by grinding debris (original magnification $X 1000$ ).

The root surfaces that were burnished with TTC for 1 minute exhibited a greater than half removal of smear layer and the presence of an indifferent fiber plexus formed by collagen fibrils of the same diameter as shown in the micrograph.(Figure 3) Areas of dentinal tubule exposure were evident.

The groups conditioned with TTC for 4 minutes either immersed or burnished (Groups III \& V) produced a smooth and regular dentinal surface

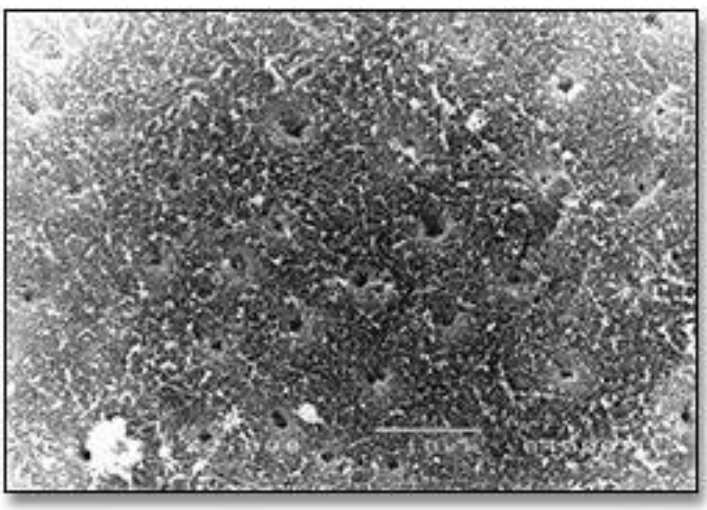

Figure 3.

Scanning electron micrograph of dentinal surface burnished in tetracycline hydrochloride for 1 minute. Dentinal tubules are visible and collagen fibrils are present on the surface (original magnification $X 2000$ ). with wide funnel-shaped tubular openings.

(Figures 4 \& 5)

The nonparametric one-way analysis of variance (Kruskal-Wallis) indicated a difference between the five groups $(p<0.0001)$.

The Tukey type nonparametric multiple range tests indicated that Group I was significantly dif ferent from the other groups $(p<0.001)$. Group II was significantly different from Groups III, IV, and $V(p<0.001)$. However, there was no significant difference between Groups III, IV, and V ( $p>0.05)$.

\section{Discussion}

This study evaluated using SEM the morphologic characteristics of diseased dentinal surfaces treat ed with TTC applied using different techniques and for a different time periods of exposure. The results presented in this study are in accordance with those of earlier studies that have found that root planing with hand instruments or burs always results in the formation of a smear layer.$^{18,19} \mathrm{~A}$ smear layer consists of organic and inorganic material and has been shown to result from root surface instrumentation with periodontal curettes ${ }^{18}$ or burs. ${ }^{19}$ Presence of this iatrogenic layer inter posed between the gingival flap and the root sur face has been suggested to impede new connec tive tissue attachment to the root following peri odontal reconstructive procedures. ${ }^{20}$ The TTC treatment disposed of the amorphous surface coating. This observation is consistent with the prevlouslY described effect of TTC on dentin. ${ }^{21,22}$ However, complete exposure of wide, funnelshaped dentinal tubules orifices were evident only in the 4 minuteapplication group with no relevant differences in the surface morphologic alterations produced in dentin between specimens treated with different demineralized techniques. There are different modes of applying the acid solution. ${ }^{23}$ The burnishing technique introduced by Miller is a marked deviation from conventional demineralization techniques including the placement method. ${ }^{24}$

The 1-minute application of TTC to the root dentin revealed some differences. Specimens immersed in TTC for 1 minute (Group II) revealed dentinal tubules that were partially occluded by grinding debris. The 1 minute burnishing application (Group IV) revealed a surface with no smear layer and the presence of intrinsic collagen fibrils, while 


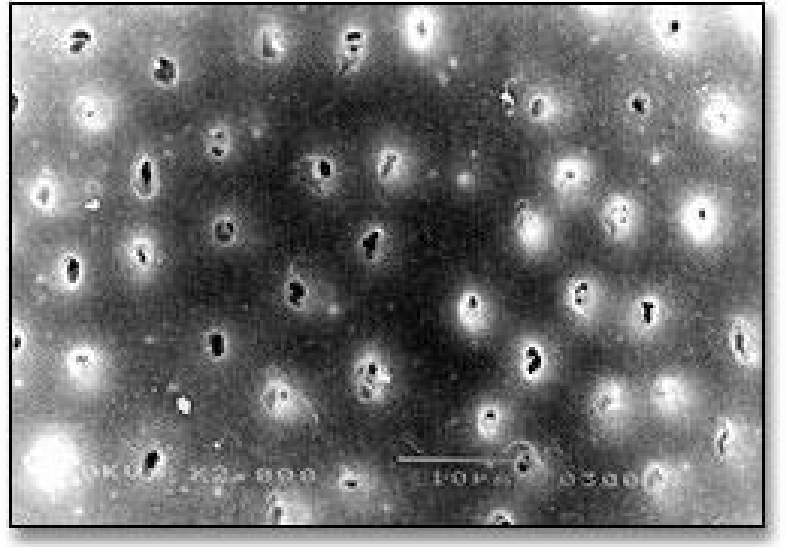

Figure 4.

Scanning electron micrograph of dentinal surface immersed in tetracycline hydrochloride for 4 minutes. Dentinal tubules in the surface of the specimen are widened. Note the presence of some grinding debris (original magnification X 2000).

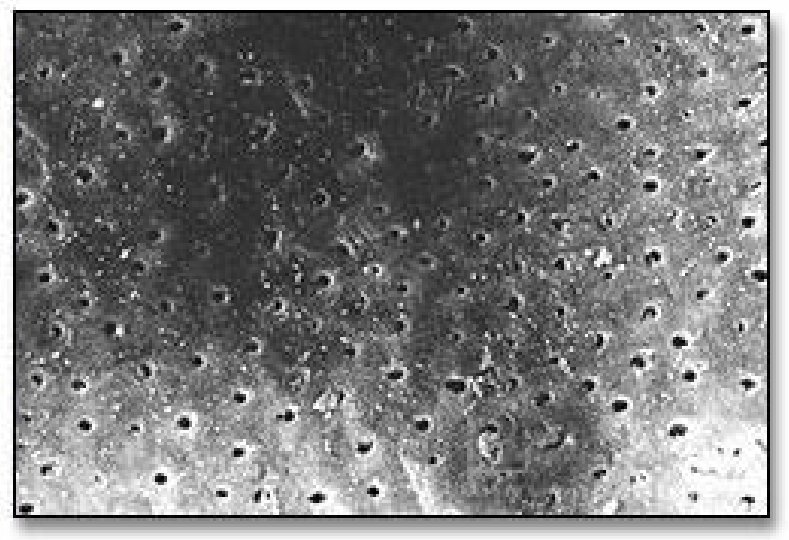

Figure 5.

Scanning electron micrograph of dentinal surface burnished with tetracycline hydrochloride for 4 minutes. Widened, funnel-shaped dentinal tubule orifices (original magnification X 1000).

the 4-minute application (Groups III and V), irre spective of the method of application used, revealed wide exposed dentinal tubules.

However, there was no statistically significant difference between the three groups (Groups III, IV, and $V$ ) $p>0.05$, probably due to the presence of fibrils in Group IV.

The fibrous appearance of exposed dentin was seen only in the 1 minute burnished group; with the 4-minute application, irrespective of the tech nique used, the dentin became dull. This concept is in agreement with Blomlöf and Lindskog who found that dentin surfaces etched with an etching agent at neutral $\mathrm{pH}$ exposed more collagen fibers than those etched with agents at low $\mathrm{pH} .{ }^{25}$ The mechanical action of burnishing seemed to dis rupt the collagenous fibers, which when the spec imens were immersed in TTC were not as affected. Hanes et al10 used tetracycline hydrochlo ride at $\mathrm{pH} 3.2$ for 4 minutes when conditioning the root surface, which did not always remove the smear layer. The contrasting finding of the present study and those of Hanes et al $^{10}$ may be explained by the lower $\mathrm{pH}$ (1.8) of TTC that was used in the present study.

It has been theorized the acid burnishing tech nique resulted in a chemical/mechanical action that enhanced the removal of chemically loos ened inorganic material and surface debris

exposing the underlying root surface to the dem ineralization action of fresh acid solution. ${ }^{26}$ This may ultimately achieve an optimal degree of dem ineralization. This concept contrasts with the findings of the Labahn et al study where the mode of applying the demineralizing solution did not appear to have any consistent effects on the mor phologic parameters studied in their study. ${ }^{13}$ One explanation may relate to the mechanical abrad ing action of the cotton pellet soaked with the demineralizing solution. Its importance could explain why in their study the depth of penetration was less in the burnished group than in the nonburnished group.

The present findings suggest that 1-minute immersion with TTC is not enough to remove the smear layer. One burnishing with TTC may be enough for smear layer removal, but that 4minute applications, irrespective of the method of application used, was adequate to completely expose the dentinal tubules. The results of this study are limited to the physical root surface changes and the potential of the tested solutions as a root surface conditioner towards the removal of the smear layer and exposure of dentinal tubules. Further investigation with the tetracyclines is needed to standardize solution concen trations, time applications, and the appropriate drug to maximize benefits as a root conditioner . 


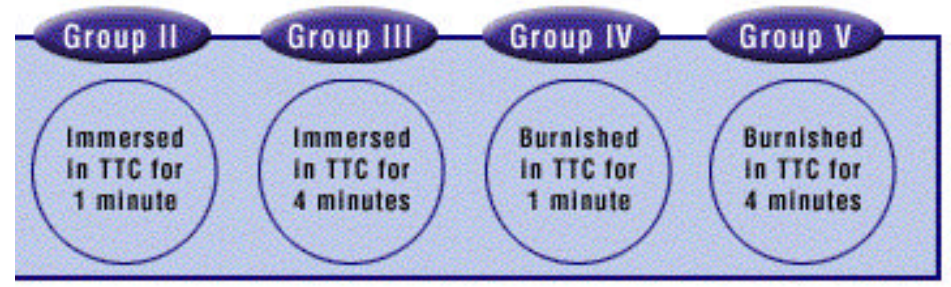

In summary, the results suggest that TTC at $\mathrm{pH} 1.8$ may alter periodontitis affected dentin removing the smear layer and exposing dentinal fibrillar collagen using a burnishing application for 1 minute. Longer application intervals at 4 minutes revealed widely exposed dentinal tubules irrespective of the conditioning method used. However, the biochemical and morphologic changes in the root surface are yet to be understood.

\section{References}

1. Hatfield CG, Baumhammers A. Cytotoxic effects of periodontally involved surfaces of human teeth. Arch Oral Biol. 1971 Apr;16(4):465-8. No abstract available.

2. Aleo JJ, De Renzis FA, Farber PA, Varboncoeur AP. The presence and biologic activity of cemen tum-bound endotoxin. J Periodontol. 1974 Sep;45(9):672-5. No abstract available.

3. Fine DH, Morris ML, Tabak L, Cole JD. Preliminary characterization of material eluted from the roots of periodontally diseased teeth. J Periodontal Res. 1980 Jan;15(1):10-9. No abstract available.

4. Adriaens PA, De Boever JA, Loesche WJ . Bacterial invasion in root cementum and radicular dentin of periodontally diseased teeth in humans. A reservoir of periodontopathic bacteria. J Periodontol. 1988 Apr;59(4):222-30.

5. Zander HA. The attachment of calculus to root surfaces. J Periodontol 1953; 24:16-19.

6.Jones WA, O'Leary TJ. The effectiveness of in vivo root planing in removing bacterial endotoxin from the roots of periodontally involved teeth. J Periodontol. 1978 Jul;49(7):337-42.

7. O'Leary TJ, Kafrawy AH. Total cementum removal: a realistic objective? J Periodontol. 1983 Apr;54(4):221-6.

8. Coldiron NB, Yukna RA, Weir J, Caudill RF. A quantitative study of cementum removal with hand curettes. J Periodontol. 1990 May;61(5):293-9.

9. Lowenguth RA, Blieden TM. Periodontal regeneration: root surface demineralization. Periodontol 2000. 1993 Feb;1:54-68. Review. No abstract available.

10. Hanes PJ, O`Brien NJ, Garnick JJ. A morphological comparison of radicular dentin following root planing and treatment with citric acid or tetracycline $\mathrm{HCl}$. J Clin Periodontol. 1991 Oct;18(9):660-8.

11. Terranova VP, Franzetti LC, Hic S, DiFlorio RM, Lyall RM, Wikesjo UM, Baker PJ, Christersson LA, Genco RJ. A biochemical approach to periodontal regeneration:

tetracycline treatment of dentin promotes fibroblast adhesion and growth. J Periodontal Res. 1986 Jul;21(4):330-7. No abstract available.

12. Vanheusden AJ, Goffinet G, Zahedi S, Nusgens B, Lapiere CM, Rompen EH. In vitro stimulation of human gingival epithelial cell attachment to dentin by surface conditioning. J Periodontol. 1999 Jun;70(6):594-603.

13.Labahn R, Fahrenbach WH, Clark SM, Lie T, Adams DF. Root dentin morphology after different modes of citric acid and tetracycline hydrochloride conditioning. J Periodontol. 1992 Apr;63(4):303-9.

14. Isik G, Ince S, Saglam F, Onan U. Comparative SEM study on the effect of different demineraliza tion methods with tetracycline $\mathrm{HCl}$ on healthy root surfaces. J Clin Periodontol. 1997 Sep;24(9 Pt 1):589-94.

15. Trombelli L, Scabbia A, Calura G. Nondiseased cementum and dentin root surface following tetra cycline hydrochloride conditioning: SEM study of the effects of solution concentration and application time. Int J Periodontics Restorative Dent. 1994 Oct;14(5):460-9. 
16. Madison JG 3rd, Hokett SD. The effects of different tetracyclines on the dentin root surface of instrumented, periodontally involved human teeth: a comparative scanning electron microscope study. J Periodontol. 1997 Aug;68(8):739-45.

17. Zahr HJ. Biostatistical Analysis. Englewood Cliffs, NJ: Prentice-Hall, 1984.

18. Jones SJ, Lozdan J, Boyde A. Tooth surfaces treated in situ with periodontal instruments. Scanning electron microscopic studies. Br Dent J. 1972 Jan 18;132(2):57-64.

No abstract available.

19. Blomlöf JP, Blomlöf LB, Lindskog SF. Smear layer formed by different root planing modalities and its removal by an ethylenediaminetetraacetic acid gel preparation. Int $\mathrm{J}$ Periodontics Restorative Dent. 1997 Jun;17(3):242-9.

20. Polson AM, Frederick GT, Ladenheim S, Hanes PJ. The production of a root surface smear layer by instrumentation and its removal by citric acid. J Periodontol. 1984 Aug;55(8):443-6.

21. Wikesjö UM, Baker PJ, Christersson LA, Genco RJ, Lyall RM, Hic S, DiFlorio RM, Terranova VP. A biochemical approach to periodontal regeneration: tetracycline treatment conditions dentin surfaces. J Periodontal Res. 1986 Jul;21(4):322-9. No abstract available.

22. Isik AG, Tarim B, Hafez AA, Yalcin FS, Onan U, Cox CF. A comparative scanning electron microscopic study on the characteristics of demineralized dentin root surface using different tetracycline $\mathrm{HCl}$ concentrations and application times. J Periodontol. 2000 Feb;71(2):219-25.

23. Wen CR, Caffesse RG, Morrison EC, Nasjleti CE, Parish UK. In vitro effects of citric acid applica tion techniques on dentin surfaces. J Periodontol. 1992 Nov;63(11):883-9.

24. Miller PD jr. Root coverage using the free soft tissue autograft following citric acid application. III. A successful and predictable procedure in areas of deep-wide recession. Int J Periodontics Restorative Dent. 1985;5(2):14-37. No abstract available.

25. Blomlöf J, Lindskog S. Periodontal tissue-vitality after different etching modalities. J Clin Periodontol. 1995 Jun;22(6):464-8.

26. Sterrett JD, Murphy HJ. Citric acid burnishing of dentinal root surfaces. A scanning electron microscopy report. J Clin Periodontol. 1989 Feb;16(2):98-104.

\section{Nadir Babay, DDS, MS, DESM}

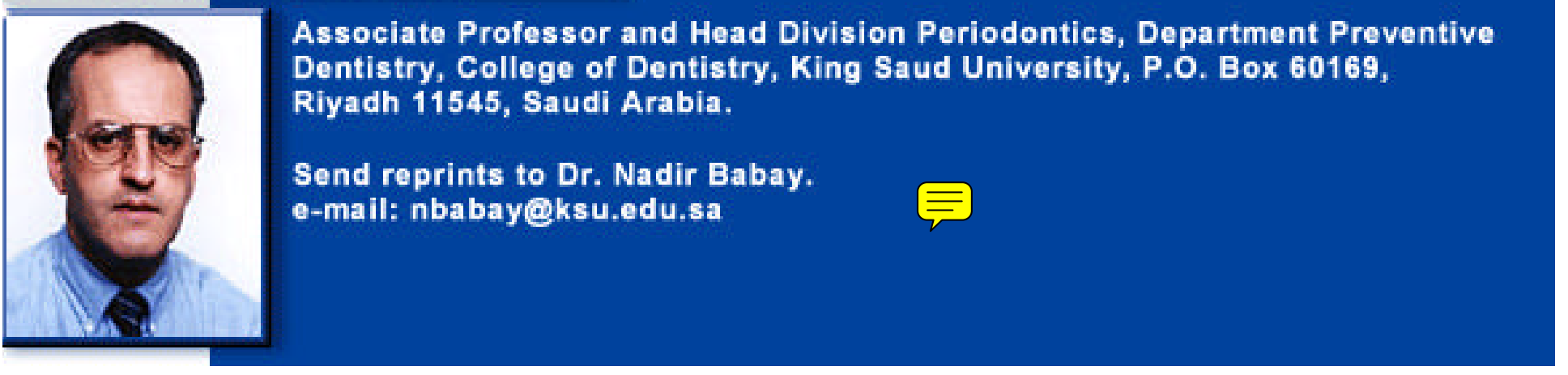

\section{Acknowledgement}

The author wishes to thank Mr. Arturo Palustre for technical assistance and Dr. Nazir Khan for statistical evaluation. 